\title{
Pengaruh Psychological Capital terhadap Work Engagement pada Karyawan
}

\author{
Muhammad Husain Hariyadi ${ }^{1}$ \\ Fakultas Psikologi, Universitas Muhammadiyah Malang \\ e-mail: ${ }^{1}$ mhhhusin@gmail.com
}

\begin{abstract}
Work engagement is defined as positive emotions, which is characterized by vigor, dedication, and absorbtion. Psychological capital is positive psychological state of someone who has the following characteristics: self-efficacy, hope, optimism, and resiliency. The purpose of this study is to examine the effect of psychological capital towards work engagement on employee. This study used quantitative method and use ramdom sampling for taking samples. The research subjects were 122 employee. The measurements used were psychological capital question (PCQ) and utrecht work engagement scale (UWES). The data analysis technique uses linear regression methods. The results showed that there was a psychological capital effect on work engagement.
\end{abstract}

KEYWORDS employee, psychological, work engagement

CITATION Hariyadi, M. H. (2019). Pengaruh psychological capital terhadap work engagement pada karyawan. Cognicia, 7, (3), 359-368.

Dunia industri sekarang ini telah mengalami perkembangan yang pesat dan akan terus menerus berkembang untuk bersaing antar industri satu dengan industri yang lainnya. Hal penting yang sangat berpengaruh bagi perkembangan tersebut adalah sumber daya manusia (SDM) di dalamnya. Karyawan sebagai sumber daya manusia (SDM) yang ada di dalamnya tentunya harus mempunyai kualitas diri yang baik dan juga keterikatan yang tinggi dengan perusahaan yang dinaunginya. Kinerja karyawan juga memiliki peran yang penting demi tercapainya tujuan dari perusahaan dalam menghadapi persaingan di era saat ini. Jika di dalam diri karyawan mempunyai rasa keterikatan (engagement) pada perusahaan maka karyawan tersebut akan mempunyai kesadaran yang tinggi untuk mengerahkan segala kemampuan terbaiknya untuk perusahaan tersebut. Work Engagement Index (WEI) mempunyai peranan yang tinggi pada beberapa hal, seperti kepuasan kerja, pertumbuhan perusahaan, keuntungan, meningkatnya produktivitas dan kenaikan saham. Dengan adanya work engagement pada karyawan ini, akan membuat karyawan merasa pekerjaan yang dilakukan dan perusahaan tempatnya bekerja memiliki arti tersendiri yang membuat karyawan tersebut dapat memberikan konstribusi yang maksimal.

Penelitian Hanggani (2017), dapat diketahui bahwa terdapat hubungan yang signifikan antara work engagement dengan disiplin kerja pada karyawan PT Kereta Api Indonesia yang terletak di Jakarta yang ditunjukkan dengan naiknya koefisien product moment. Work engagement memberikan pengaruh yang signifikan terhadap disiplin kerja pada karyawan PT KA Indonesia, hal tersebut menunjukkan bahwa semakin 
tinggi work engagement karyawan akan memberikan pengaruh terhadap semakin tingginya disiplin kerja pada karyawan. Penelitian yang dilakukan oleh Wakhyuni (2016), bertujuan untuk menguji ada tidaknya hubungan antara work engagement dan organizational efficacy. Organizational efficacy pada karyawan PT Yuro Mustika berada dalam kategori sedang dengan aspek yang sangat berpengaruh adalah sense of mission, future or purpose. Kondisi work engagement karyawan PT Yuro Mustika berada dalam kategori sedang dengan dimensi yang sangat berpengaruh adalah vigor atau energy, serta ketahanan mental saat menghadapi hambatan dalam bekerja. Selanjutnya penelitian yang dilakukan oleh Lisbona, Palaci, Salanova, dan Frese (2018) yaitu dua konsep populer, keterikatan kerja dan inisiatif pribadi. Studi ini didasarkan pada memperluas model inisiatif pribadi, dan hasil dari dua studi ini mengkonfirmasi bahwa work engagemeng dan self-efficacy mengarah pada inisiatif pribadi yang lebih tinggi, serta mengarah pada kinerja yang lebih tinggi. Selain mempertimbangkan work engagement sebagai anteseden inisiatif pribadi, hasilnya mengarah pada mempertimbangkan inisiatif pribadi sebagai anteseden kinerja.

Penelitian yang dilakukan Handayani (2016) hasil penelitian tersebut menunjukan bahwa korelasi yang positif antara work engagament dengan organizational citizenship behavior pada karyawan kontrak. Hal ini menunjukan bahwa semakin tinggi work engagement maka akan semakin tinggi pula organizational citizenship behavior pada karyawan kontrak, dan begitu pula sebaliknya semakin rendah work engagement maka akan semakin rendah pula organizational citizenship behavior pada karyawan kontrak. Selanjutnya di dalam penelitian Manish Gupta, (1960) diketahui secara keseluruhan, bahwa investigasi pada pemahaman niat keterikatan kerja untuk pergantian hubungan dihasilkan dalam menggeneralisasi temuan sebelumnya dalam konteks saat ini. Namun, hasil tersebut menunjukkan bahwa hubungan ini dipengaruhi secara signifikan dengan perubahan tingkat modal psikologis, sehingga untuk karyawan yang mampu secara psikologis, hubungan antara keterikatan kerja dan niat untuk turnover akan lebih kuat. Sebaliknya, untuk karyawan yang kurang secara psikologis, hubungan antara keterikatan kerja dan niat untuk turnover akan terjadi lebih lemah. Dalam penelitian Salu dan Hartijasi, (2018) hasil penelitian menunjukkan bahwa work engagement memiliki efek yang positif sebagai mediator untuk hubungan antara job resources dan transformational leadership terhadap komitmen organisasi dan job resources. Efek maksimum ditemukan dalam hubungan antara transformasional leadership dengan komitmen organisasi melalui work engagement sebagai mediator.

Penelitian Rongen, Robroek, Schaufeli, dan Burdorf (2014), work engagement berkontribusi pada kemampuan kerja di luar perilaku kesehatan yang diketahui dan karakteristik terkait pekerjaan. Persepsi tentang kesehatan dan penyakit yang dirasakan oleh seseorang belum terlalu diprediksi oleh perilaku kesehatan, sedangkan kemampuan kerja sebagian besar diprediksi oleh karakteristik yang berhubungan dengan pekerjaan. Keterikatan kerja terkait dengan kemampuan kerja dan tidak adanya penyakit jangka panjang. Lalu dalam penelitian yang dilakukan Mewengkang dan Panggabean (2016), dari hasil statistik, diperoleh hasil bahwa terdapat perbedaan yang signifikan pada data demografi masa kerja, dimana kelompok masa kerja 1 hingga 5 tahun memiliki skor terendah dibandingkan dengan kelompok masa kerja yang lainnya. Mengingat pentingnya untuk meningkatkan work engagement karyawan 
agar dapat mendukung efektivitas perusahaan, maka dirancang sebuah intervensi untuk program sosialisasi, penyusunan form rencana kerja karyawan dan pemberian feedback dari atasan yang disertai dengan form monitoring. Di dalam penilitian Reijseger, Schaufeli, Peeters, dan Taris (2010), mempresentasikan ide-idenya mengenai hubungan antara keterikatan kerja dan kinerja dalam kerangka kerja teoritis. Akhirnya, pada hasil studi ini mengusulkan dua penjelasan tentang mengapa tingkat keterikatan kerja yang tinggi membuat karyawan berkinerja lebih baik daripada tingkat keterikatan kerja yang rendah.

Penelitian Hamid dan Yahya (2016), studi ini melaporkan bahwa personal job yang langsung mempengaruhi employee's retention dan work engagement. Temuan juga mengkonfirmasi efek work engagement sebagai variabel mediasi dalam hubungan antara personal job dan employee's retention. Studi ini memberikan dukungan pada faktor individu, khususnya personal job dan work eengagement sebagai faktor penting dalam mempertahankan karyawan, terutama pada insinyur. Di dalam penilitian Santoso dan Jatmika (2017) dapat dilihat bahwa terdapat hubungan antar variabel, yaitu variabel resiliensi dan work engagement, maka dapat dikatakan ketika resiliensi agen tinggi, maka work engagement akan tinggi pula, begitupun sebaliknya. Sehingga peniliti menyarankan agar pihak perusahaan asuransi. Dalam penelitian Nugroho, Mujiasih, dan Prihatsanti (2013), hasil ini mengindikasikan bahwa terdapat hubungan positif antara psychological capital dan work engagement. Semakin tinggi psychological capital maka semakin tinggi work engagement.

Penelitian Kimberly dan Utoyo (2013), menunjukkan bahwa terdapat hubungan yang positif antara psychological well-being dan work engagement, yang peningkatan pada psychological well-being diikuti dengan peningkatan pada work engagement karyawan. Dalam penelitian Man dan Hadi (2013), desain penelitian yang menggunakan korelasi Spearmen menemukan bahwa, or su dan work enggament mempunyai hubungan positif yang tidak kuat. Berarti, semakin tingginya persepsi terhadap organisasi, semakin tinggi pula hubungan keterikatan kerja seseorang. Dalam penelitian Altunel (2015), hasilnya dianalisis menggunakan pemodelan persamaan struktural. Hasilnya menunjukkan bahwa sumber daya pekerjaan (otonomi, dukungan sosial, pelatihan, peluang untuk pengembangan pribadi, dan signifikansi tugas) perlu ditingkatkan untuk mengembangkan keterikatan kerja oleh akademisi Turki. Selanjutnya dalam penelitian Alzyoud, Othman, dan Isa (2015), hasil menunjukkan bahwa otonomi, dukungan sosial dan umpan balik kinerja adalah faktor signifikan dalam mempengaruhi keterikatan kerja akademisi. Temuan ini umumnya mendukung temuan masa lalu, yang menyarankan bahwa karyawan lebih mungkin untuk terlibat dengan pekerjaan mereka jika mereka diberi otonomi, dukungan sosial, dan umpan balik kinerja.

Penelitian Indrianti dan Hadi (2012) temuan data penelitian ini memiliki korelasi antrara dua variabel dengan taraf signifikansi 0,053. Dapat dilihat bahwa, tidak adanya korelasi antara modal psikologis dengan keterikatan kerja perawat di instansi Rumah Sakit Jiwa Menur Surabaya. Akan tetapi penelitian tersebut bertentangan dengan penelitian lainnya. Penelitian Rotich, Cheruiyot, dan Korir (2016), studi ini 
menunjukkan bukti bahwa optimisme mempengaruhi keterikatan kerja lebih dari faktor demografis. Karyawan dapat menunjukkan tingkat keterikatan kerja yang tinggi ketika mereka secara psikologis positif tentang masa depan mereka.

Penelitian Suharianto, Effendy, dan Unika (2015), temuan penelitian ini menunjukkan adanya pengaruh antara psychologiocal capital dan work engagement terhadap dosen pengajar di Universitas Katolik Widya Mandala Surabaya. Diketahui, bahwasannya terdapat kecenderungan semakin tinggi psychological capital tenaga dosen pengajar, semakin tinggi pula work engagement. Lalu dalam penelitian Erbasi dan Ozbek (2016), dapat dilihat bahwa ketika tingkat kemandirian, harapan, dan daya tahan meningkat, keterikatan kerja mereka dapat dikatakan meningkat. Dalam penelitian ini, pengaruh dimensi modal psikologis pada setiap dimensi keterikatan kerja diperiksa. Menurut hasil yang diperoleh, dimensi harapan, daya tahan, dan optimisme memprediksi dimensi kekuatan; self-efficacy, harapan, daya tahan, dan optimisme memprediksi dimensi konsentrasi. Selanjutnya dalam penelitian Ferreira (2015), menemukan bahwa modal psikologis mempengaruhi keterikatan kerja di antara sampel petugas pemasyarakatan, khususnya dimensi modal psikologis yang memengaruhi kekuatan dimensi keterikatan kerja. Selanjutnya, optimisme menjelaskan proporsi terbesar dari varian dalam keterlibatan kerja. Diketahui bahwa tempat kerja yang berbeda menunjukkan hasil yang berbeda terkait dengan korelasi antara psychological capital terhadap work engagement. Dengan kata lain ada temuan yang berbeda-beda mengenai pengaruh psychological capital terhadap work engagement, sehingga perlu adanya penelitian lebih lanjut.

Menurut penelitian yang dilakukan oleh Tolman dan Wiker (2012) karyawan yang tidak memiliki engagement dengan pekerjaannya akan menambah biaya yang dikeluarkan oleh organisasi. Karyawan dengan work engagement rendah cenderung tidak terlalu mempedulikan pekerjaannya, berusaha untuk keluar, mengeluarkan usaha yang sedikit, lebih sering absen, serta menimbulkan turnover lebih pada organisasi. Karyawan dengan engagement yang rendah tentu saja menambah biaya yang dikeluarkan organisasi untuk pelatihan karyawan baru dan kompensasi untuk karyawan. Jika dari waktu ke waktu terdapat banyak karyawan dengan work engagement yang rendah tentu saja akan merugikan organisasi, selain menambah pengeluaran pada organisasi, karyawan yang memiliki work engagement rendah juga akan mengurangi produktivitas organisasi.

Setelah mengetahui penjelasan di atas, dapat diketahui bahwa banyak aspek yang dapat mempengaruhi dan dipengaruhi oleh work engagement, tetapi pada aspek psychological capital masih sedikit yang meneliti mengenai topik ini, serta hasil yang adapun dari beberapa penelitian masih tidak konsisten. Berdasarkan hal tersebut, peneliti ingin meneliti lebih lanjut mengenai pengaruh psychological capital terhadap work engagement dikarenakan masih sedikit hasil yang ditemukan dan belum banyak ditemukan hasil yang memiliki hubungan positif.

\section{METODE}

Penelitian ini menggunakan variabel psychological capital sebagai variabel $\mathrm{x}$, dan work engagement sebagai variabel y. Subjek yang digunakan dalam penelitian ini merupakan karyawan. Karyawan yang akan diberi skala berjumlah 100 subjek. 
Prosedur penelitian yang pertama, peneliti melakukan pendalaman materi. Setelah itu, peneliti menyiapkan instrumen. Instrumen yang digunakan adalah UWES (Utrecth Work Engagement Scale) milik Schaufeli dan Bakker (2004) dan PCQ (Psychological Capital Questionare) milik Luthans et al. (2007). Setelah itu melakukan try-out, dan dianalisa menggunakan teknik analisa faktor. Selanjutnya, peneliti menyebarkan skala kepada subjek yang memenuhi persyaratan, yaitu karyawan. Data yang telah didapat akan dimasukkan dan diolah dengan program perhitungan statistic SPSS 21, dengan teknik analisis regresi linear untuk menguji apakah variabel prediktor dapat menjadi kriteria determinan variabel.

\section{HASIL}

Subjek dalam penelitian ini adalah karyawan. Total subjek dalam penelitian ini adalah 122 karyawan. Berikut data deskriptif karyawan yang dijadikan sampel penelitian.

Tabel 1. Deskripsi subjek penelitian

\begin{tabular}{lcc}
\hline \multicolumn{1}{c}{ Kategori } & Frekuensi & Persentase \\
\hline Jenis kelamin & & \\
Laki-laki & 54 & 44,3 \\
Perempuan & 68 & 55.7 \\
Tempat Kerja & & \\
Pendidikan & 12 & 9.8 \\
Kesehatan & 61 & 50.0 \\
Finance & 16 & 13.1 \\
BUMN & 33 & 27.0 \\
Status & & \\
Belum Menikah & 26 & 21.3 \\
Menikah & 93 & 76.2 \\
Duda/Janda & 3 & 2.5 \\
Lama Bekerja & & \\
1-10 tahun & 66 & 54.1 \\
11-20 tahun & 30 & 24.6 \\
21-30 tahun & 24 & 19.7 \\
$>30$ tahun & 2 & 1.6 \\
\hline
\end{tabular}

Pada tabel di atas, dapat dilihat bahwa pada jenis kelamin, mayoritas adalah perempuan, dengan persentase $55.7 \%$. Untuk kategori tempat kerja, mayoritas subjek bekerja di kesehatan, dengan persentase 50\%. Selanjutnya pada kategori status, mayoritas menikah, dengan persentase $76.2 \%$. Terakhir kategori lama bekerja, mayoritas subjek berada di 1-10 tahun, dengan persentase $54.1 \%$.

Selanjutnya skor pada psychological capital dan work engagement dikategorikan berdasarkan pada tinggi rendah sesuai dengan penormaan. Berikut adalah kategorisasi skor psychological capital dan work engagement. 
Tabel 2. Deskripsi variabel

\begin{tabular}{lcccccc}
\hline & Kategori & Interval & Frekuensi & Persentase & Mean & SD \\
\hline Work Engagement & Tinggi & $X>50$ & 64 & $52.5 \%$ & 4.54 & 0.69 \\
& Rendah & $X \leq 50$ & 58 & $47.5 \%$ & & \\
Psychological & Tinggi & $X>50$ & 63 & $51.6 \%$ & 4.53 & 0.68 \\
Capital & Rendah & $X \leq 50$ & 59 & $48.4 \%$ & & \\
\hline
\end{tabular}

Dari tabel di atas, dapat terlihat bahwa skor work engagement lebih besar pada kategori tinggi daripada kategori rendah, yaitu 52.5\%, begitupun pada skor psychological capital lebih besar pada kategori tinggi, yaitu 51.6\%.

Untuk mengetahui ada tidaknya pengaruh psychological capital terhadap perilaku work engagement, peneliti melakukan analisis regresi linear. Berikut hasil pengukuran yang didapat.

Tabel 3. Analisa regresi linear

\begin{tabular}{cccc}
\hline \multirow{2}{*}{ Kategori } & \multicolumn{3}{c}{ Work Engagement } \\
\cline { 2 - 4 } & $\boldsymbol{\beta}$ & $\boldsymbol{\beta}^{2}$ & $\boldsymbol{p}$ \\
\hline Psychological Capital & 0.584 & 0.341 & 0.000 \\
\hline
\end{tabular}

Dari hasil analisa yang telah dilakukan menggunakan analisa regresi linear, diperoleh angka koefisien $\mathrm{R}$ sebesar 0.584. Angka positif tersebut menunjukkan bahwa terdapat korelasi searah antara psychological capital dan work engagement. Hal ini juga dapat diketahui bahwa terjadi hubungan yang kuat antara kedua variabel, menurut Sarwono (2006) nilai koefisien >0.5-0.75 termasuk dalam kriteria korelasi yang kuat. Karena nilai $R$ berkisar antara 0 sampai 1 dan lebih mendekati ke 1, maka hubungan yang terjadi semakin kuat. Sebaliknya, nilai semakin mendekati 0 maka hubungan yang terjadi semakin lemah.

Dari analisa regresi linear juga didapat besarnya koefisien determinasi yang ditunjukkan oleh nilai $\mathrm{R}$ square $=0.341$. Hal ini berarti sumbangan efektif dari variabel psychological capital terhadap variabel work engagement hanya sebesar $34.1 \%$ sehingga $65.9 \%$ dipengaruhi oleh faktor lain yang tidak masuk dalam penelitian. Angka pada signifikasi menunjukkan apakah variabel independen berpengaruh terhadap variabel dependen, dimana jika nilai signifikasi $<0.5$ maka variabel psychological capital berpengaruh signifikan terhadap variabel work engagement. Dapat diketahui hasil pengujian signifikasi mennunjukkan bahwa nilai probabilitas sebesar $0.000(0.000<$ 0.05). Nilai tersebut menunjukkan adanya pengaruh signifikan pada psychological capital terhadap work engagement.

\section{DISKUSI}

Penelitian yang sudah dilakukan, didapat hasil bahwa ada pengaruh positif yang signifikan pada psychological capital terhadap work engagement pada karyawan. Hal ini menunjukkan bahwa semakin tinggi perkembangan positif karyawan maka akan tinggi pula keterikatan kerja. Perkembangan positif karyawan di sini adalah individu yang mampu untuk meningkatkan motivasi dalam melaksanakan tugas, mencari 
alternative untuk mencapai tujuan, dan bertahan disaat masa terpuruk. Keterikatan kerja yang dimaksud adalah individu yang memiliki kemampuan untuk mengidentifikasi diri secara psikologis dengan pekerjaannya.

Hasil penelitian ini sejalan dengan beberapa penelitian sebelumnya, seperti penelitian Suharianto, Effendy, dan Unika (2015), temuan penelitian ini menunjukkan adanya pengaruh antara psychologiocal capital dan work engagement terhadap dosen pengajar di Universitas Katolik Widya Mandala Surabaya. Maka dapat disimpulkan terdapat kecenderungan dosen yang memiliki psychological capital yang tinggi akan cenderung mempunyai work engagement yang tinggi pula. Ferreira (2015), menemukan bahwa modal psikologis mempengaruhi keterikatan kerja di antara sampel petugas pemasyarakatan, khususnya dimensi modal psikologis yang memengaruhi kekuatan dimensi keterikatan kerja. Namun penelitian ini tidak sejalan dengan penelitian Indrianti dan Hadi (2012) dapat disimpulkan bahwa tidak terdapat korelasi antara modal psikologis terhadap keterikatan kerja pada perawat di instalasi rawat inap Rumah Sakit Jiwa Menur Surabaya.

Psychological capital memberikan kontribusi sebesar $34.1 \%$ terhadap work engagement pada karyawan. Sehingga $65.9 \%$ sisanya dipengaruhi oleh faktor lainnya. Pada penelitian Kimberly dan Utoyo (2013), hasil penelitian menunjukkan terdapat hubungan positif yang signifikan pada psychological well-being dan work engagement, yang peningkatan pada psychological well-being diikuti dengan peningkatan pada work engagement karyawan. Penelitian Man dan Hadi (2013), hasil analisa data penelitian tersebut menggunakan korelasi Spearman menyatakan bahwa perceived organizational support dan work engagement mempunyai hubungan positif yang lemah. Semakin tingginya persepsi pada organisasi maka semakin tinggi keterikatak kerja karyawan tersebut. Penelitian di atas menunjukkan faktor-faktor yang mempengaruhi work engagement.

Penelitian yang sejalan oleh Min, Kim, dan Lee (2015) menunjukkan hasil bahwa, psychological capital pada karyawan akan memiliki dampak yang negatif terhadap tantangan dan pemicu stres pada kelelahan saat bekerja. Sehingga, karyawan yang memiliki psychological capital yang tinggi, maka work engagement akan meningkat, begitupula ketika karyawan yang memiliki psychological capital rendah, maka work engagement akan menurun. Begitupun dengan penelitian Paek, Schuckert, Kim, dan Lee (2015) menunjukkan hasil bahwa karyawan yang bekerja sebagai resepsionis dengan psychological capital yang tinggi akan lebih terlibat dengan pekerjaannya, dan cenderung untuk lebih menampilkan kepuasan kerja dan komitmen organisasi yang efektif.

Hasil penelitian juga menunjukkan bahwa work engagement cenderung tinggi dengan persentase sebesar $52.5 \%$ dan psychological capital cenderung tinggi dengan persentase sebesar $51.6 \%$. Hal ini menguatkan hipotesa yang diterima dalam penelitian ini. Ada pengaruh positif antara psychological capital terhadap work engagement. Artinya, semakin tinggi psychological capital maka akan semakin tinggi pula work engagement.

Berdasarkan penelitian Sister dan Aifang (2018), didapat hasil bahwa variabel demografis pada perawat seperti, tingkat pendidikan, departemen kerja, dan gender 
berkaitan dengan variabel psychological capital maupun work engagement. Artinya, pada tingkat pendidikan yang berbeda, diketahui psychological capital perawat memiliki perbedaan. Hal serupa juga terjadi dengan work engagement, dapat diketahui bahwa tingkat pendidikan memiliki perbedaan. Selanjutnya pada variabel gender juga memiliki hasil yang berbeda pada psychological capital dan work engagement.

Berdasarkan pembahasan diatas, terdapat beberapa kelebihan penelitian. Pertama, kontribusi yang cukp tinggi, yaitu 34.1\%. Beberapa kelemahan dalam penelitian ini yaitu, kriteria subjek yang digunakan masih terlalu general. Kekurangan lainnya skala yang digunakan masih terlalu umum, namun sejalan dengan kriteria subjek yang umum pula.

\section{SIMPULAN DAN IMPLIKASI}

Berdasarkan hasil penelitian, dapat diperoleh hasil bahwa hipotesa penelitian diterima, sehingga menunjukkan pengaruh positif antara psychological capital terhadap work engagement pada karyawan. Hal tersebut menunjukkan bahwa semakin tinggi psychological capital maka akan tinggi pula work engagement. Sebaliknya, semakin rendah psychological capital maka akan rendah work engagement. Besar pengaruh psychological capital terhadap work engagement adalah $34,1 \%$.

Penelitian ini memiliki beberapa implikasi. Bagi perusahaan/instansi tempat subjek bekerja, penelitian ini dapat digunakan bahan pertimbangan untuk keperluan analisa jabatan. Selain itu, penelitian dapat digunakan untuk bahan evaluasi job description, sehingga tidak terjadi ketidak sesuaian penempatan kerja. Bagi subjek penelitian, hasil dapat dijadikan referensi untuk memaknai pekerjaan subjek saat ini. Bagi peneliti selanjutnya, dapat memfokuskan bidang pekerjaan tertentu untuk meneliti variabel terkait. Implikasi lainnya, peneliti dapat mengaitkan work engagement dengan variabel lain, seperti disiplin kerja, organizational efficacy, dan job resources.

\section{REFERENSI}

Altunel, M. C. (2015). The effect of job resources on work engagement: A study on academicians in Turkey, 15(2), 409-417. https://doi.org/10.12738/estp.2015.2.2349

Alzyoud, A. A. Y., Othman, S. Z., \& Isa, M. F. M. (2015). Examining the role of job resources on work engagement in the academic setting. Asian Social Science, 11(3). https://doi.org/10.5539/ass.v11n3p103

Bakker, A. B., \& Demerouti, E. (2008). Towards a model of work engagement. Career Development International, 13, 209-223.

Bakker, A. B., \& Leiter, M. P. (2010). Work engagement: A handbook of essential theory and research. New York: Psychology Press.

Bakker, A. B., Schaufeli, W. B., Leiter, M. P., \& Taris, T. W. (2002). Work engagement: An emerging concept in occupational health psychology. Journal of Work \& Stress, 187-200.

Brown, S. P. (1996). A meta-analysis and review of organizational research on job involvement. Psychological Bulletin, 120, 235-255.

Creswell, J. W. (2010). Research design: pendekatan kualitatif, kuantitatif, dan mixed. Yogyakarta: PT Pustaka Pelajar.

Erbasi, A., \& Ozbek, M. C. (2016). The effect of psychological capital on work engagement. 
Australian Academy of Business and Economics Review ( AABER ), 2(4), 276-284.

Fatih, C., \& Nejat, B. (2012). Organizational psychological capital: A scale organizational psychological capital : A scale adaptation study, 6(March), 159-179.

Ferreira, T. (2015). The relationship between psychological capital and work engagement amongst correctional officers at a correctional facility in the western cape, (November).

Gupta, M., \& Shaheen, M. (2017). Impact of work engagement on turnover intention: Moderation by psychological capital in India. Annales Médico-Psychologiques, 18(1), 136143. https://doi.org/10.3846/btp.2017.790

Hamid, S. N. A., \& Yahya, K. K. (2016). Mediating role of work engagement on the relationship between person-job fit and employees ' retention: Evidence from semiconductor companies in Northern Region of Malaysia, 6, 187-194.

Handayani, D. A. (2016). Hubungan antara work engagement organizational citizenship behavior pada karyawan kontrak. Jurnal Ilmiah Psikologi, 9(1), 58-68.

Hanggani. (2017). Hubungan antara work engagement dengan disiplin kerja karyawan kantor PT. Kereta api Indonesia (PERSERO) DAOP 1 Jakarta, 91, 399-404.

Indrianti, R., \& Hadi, C. (2012). Hubungan antara modal psikologis dengan keterikatan kerja pada perawat di instalasi rawat inap rumah sakit jiwa menur Surabaya. Jurnal Psikologi Industri Dan Organisasi, 1(02), 110-115.

Kahn, W. A. (1990). Psychological conditions of personal engagement and disengagement at work. Academy of Management Journal, 33, 692-724.

Kimberly, \& Utoyo, S. D. B. (2013). Hubungan psychological well-being dan work engagement pada karyawan yang bekerja di lokasi tambang.

Lisbona, A., Palaci, F., Salanova, M., \& Frese, M. (2018). The effects of work engagement and self-efficacy on personal initiative and performance. Psicothema, 30(1), 89-96. https://doi.org/10.7334/psicothema2016.245

Luthans, F., Youssef, C. M., \& Avolio, B. J. (2007). Psychological capital: Developing the human competitive edge. New York: Oxford University Press.

Man, G. S., \& Hadi, C. (2013). Hubungan antara perceived organizational support dengan work engangement pada guru SMA swasta di Surabaya. Jurnal Psikologi Industri Dan Organisasi, 2(2), 90-99.

Mewengkang, M., \& Panggabean, H. (2016). Work engangement karyawan MBN terhadap implementasi aplikasi data analisis SDM. Jurnal Ilmiah Psikologi MANASA, 5(1), 1-14.

Min, H., Kim, H. J., \& Lee, S.-B. (2015). Extending the challenge-hindrance stressor framework: The role of psychological capital. International Journal of Hospitality Management, 50, 105114. https://doi.org/https://doi.org/10.1016/j.ijhm.2015.07.006

Nugroho, D. A. S., Mujiasih, E., \& Prihatsanti, U. (2013). Hubungan antara psychological capital dengan work engagement pada karyawan PT. Bank Mega Regional Area Semarang. , 12(2),. Jurnal Psikologi Undip, 12(2), 191-202.

Paek, S., Schuckert, M., Kim, T. T., \& Lee, G. (2015). Why is hospitality employees' psychological capital important? The effects of psychological capital on work engagement and employee morale. International Journal of Hospitality Management, 50, 9 26. https://doi.org/https://doi.org/10.1016/j.ijhm.2015.07.001

Reijseger, G., Schaufeli, W. B., Peeters, M. C. W., \& Taris, T. W. (2010). A model of the relation between work engagement and job performance. Occupational Health Psychology: From Burnout to Well-Being, 287-306.

Rongen, A., Robroek, S. J. W., Schaufeli, W., \& Burdorf, A. (2014). The contribution of work engagement to self-perceived health, work ability, and sickness absence beyond health behaviors and work-related factors. Journal of Occupational and Environmental Medicine, 
56(8), 892-897. https://doi.org/10.1097/JOM.196

Rotich, R. K., Cheruiyot, T. K., \& Korir, M. K. (2016). Effects of demographics on the relationship between optimism and work engagement among employees of state agencies in Kenya. Journal of Resources Development and Management, 18, 32-42.

Salu, O. J. R., \& Hartijasi, Y. (2018). Analisis pengaruh work engagement sebagai mediator antara job resources dan kemimpinan transformal terhadap organizational commitmen dan job performance di lembaga pendidikan Indonesia Amerika. Jurnal Bisnis, Manajemen Dan Informatika ANALISIS, Vol. 14 No, 171-192.

Santoso, M. R., \& Jatmika, D. (2017). Hubungan resiliensi dengan work engangement pada agen asuransi PT. X. Jurnal Ecopsy, 4(2), 117-123.

Sarwono, J. (2006). Metode penelitian kuantitatif. Yogyakarta: Graha Ilmu.

Schaufeli, W., \& Bakker, A. (2004). Utrecht work engangement scale. Occupational Health Psychology Unit.

Schaufelli, W. B., Salanova, M., Goza'lez-Roma', V., \& Bakker, A. B. (2002). The measurment of engagement and burnout: A two sample confirmatory factor analytic approach. Journal of Happiness Studies, 3, 71-92.

Sister, G. B., \& Aifang, Z. (2018). The relationship among Psychological capital Psychological Contract and Work Engagement in Nurses. Chinese Journal of Occupational Health and Occupational Diseases, 36(8), 614-617. https://doi.org/10.3760/cma.j.issn.10019391.2018.08.013

Sugiyono. (2014). Metode penelitian kuatitatif, kualitatif dan RED. Bandung: Alfabeta.

Suharianto, \& Effendy, N. (2015). Pengaruh psychological capital terhadap work engagement pada dosen di universitas katolik widya mandala Surabaya. Jurnal Experientia, 3(2), 23-34.

Tolman, \& Wiker. (2012). Why employee engagement has a direct impact on your business bottom line. Retrieved from http://tolmanandwiker.com/employee-engagement-directimpact-business-bottom-line/

Wakhyuni, D. S. (2016). Hubungan work engagement dan organizational efficacy. Jurnal Ilmiah Psikologi, 8(3), 156-162. https://doi.org/10.1177/1077559508318396 